\title{
光受容タンパク質による微生物の光センシングの理解とその利用
}

\author{
須藤雄 気, ${ }^{*, a, b}$ 本間 道夫 ${ }^{a}$
}

\section{Photosensing by Membrane-embedded Receptors and Its Application for the Life Scientists}

\author{
Yuki Sudo*,a,b and Michio Homma ${ }^{a}$ \\ ${ }^{a}$ Division of Biological Science, Graduate School of Science, Nagoya University; Furo-cho, \\ Chikusa-ku, Nagoya 464-8602, Japan: and ${ }^{b}$ PRESTO, Japan Science and Technology \\ Agency (JST); 4-1-8 Honcho, Kawaguchi, Saitama 332-0012, Japan.
}

(Received October 11, 2011)

\begin{abstract}
Light is one of the most important energy sources and signals providing critical information to biological systems. The photoreceptor rhodopsin, which possesses retinal chromophore (vitamin A aldehyde) surrounded by seven transmembrane alpha-helices, is widely dispersed in prokaryotes and in eukaryotes. Although rhodopsin molecules work as distinctly different photoreceptors, they can be divided according to their two basic functions such as light-energy conversion and light-signal transduction. Thus rhodopsin molecules have great potential for controlling cellular activity by light. Indeed, a light-energy converter channel rhodopsin is used to control neural activity. From 2001, we have been working on various microbial sensory rhodopsins functioning as light-signal converters. In this review, we will introduce rhodopsin molecules from microbes, and will describe artificial and light-dependent protein expression system in Escherichia coli using Anabeana sensory rhodopsin (ASR). The newly developed tools would be widely useful for life scientists.
\end{abstract}

Key words_— photoactive protein; rhodopsin; signal transduction; membrane protein

\section{1.はじめに}

日本人の好きな食べ物リストには, 今も昔もカ レーライスが上位にランキングされている，私も御 多分に漏れず大好物である. カレーライスに必要な コメ，ジャガイモ，ニンジンなどは，太陽光のエネ ルギーを変換し蓄えた結果として得られる。 また, 私たちはスーパーに並んだ食材の色や形の情報を目 で認識し，好みのニンジンや牛肉を購入する．この ように, カレーライスの例を持ち出すまでもなく, 光（太陽光）は, 生命にとつて極めて重要なエネル ギー源であるとともに情報源である. ${ }^{1)}$

生体内で, 光をエネルギーや情報に変換するの は，タンパク質分子である（Fig. 1)。ところが一

a名古屋大学大学院理学研究科生命理学専攻 (T4648602 名古屋市千種区不老町), ${ }^{b}$ 科学技術振興機構 （JST）さきがけ（テ332-0012 埼玉県川口市本町 4-18)

*e-mail: z47867a@ @c.nagoya-u.ac.jp

本総説は, 日本薬学会第 131 年会シンポジウム OS02

で発表したものを中心に記述したものである.
般にタンパク質は，（透明であることが示すように） 可視部に吸収を持たず，光を受容できない。そのた め，可視部に吸収を持つ発色団をタンパク質内部に 内包する必要がある。自然界には様々な発色団が存 在し，それぞれのタンパク質に取り込まれること で，光受容体となる (Fig. 1). 1) ここで, 〜 rhodop-

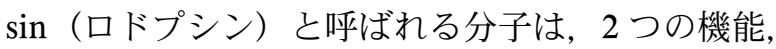
すなわち光でエネルギーを産生することが可能であ るだけでなく，光を情報に変換することが可能な分 子であることに気づく. ${ }^{2}$ 私たちは, 特に微生物由 来のこれら分子に着目し研究を行っている.ここで は，ロドプシン分子の光情報変換機構についての研 究成果を概説するとともに，近年急速に発展してい る光による細胞・個体操作（いわゆるオプトジェネ ティクス）について取り上げる.

\section{2. ロドプシン類}

ロドプシンタンパク質はレチナールタンパク質と も呼ばれ，ビタミン A のアルデヒド型であるレチ ナール（そのためビタミン A が目によいと言われ 


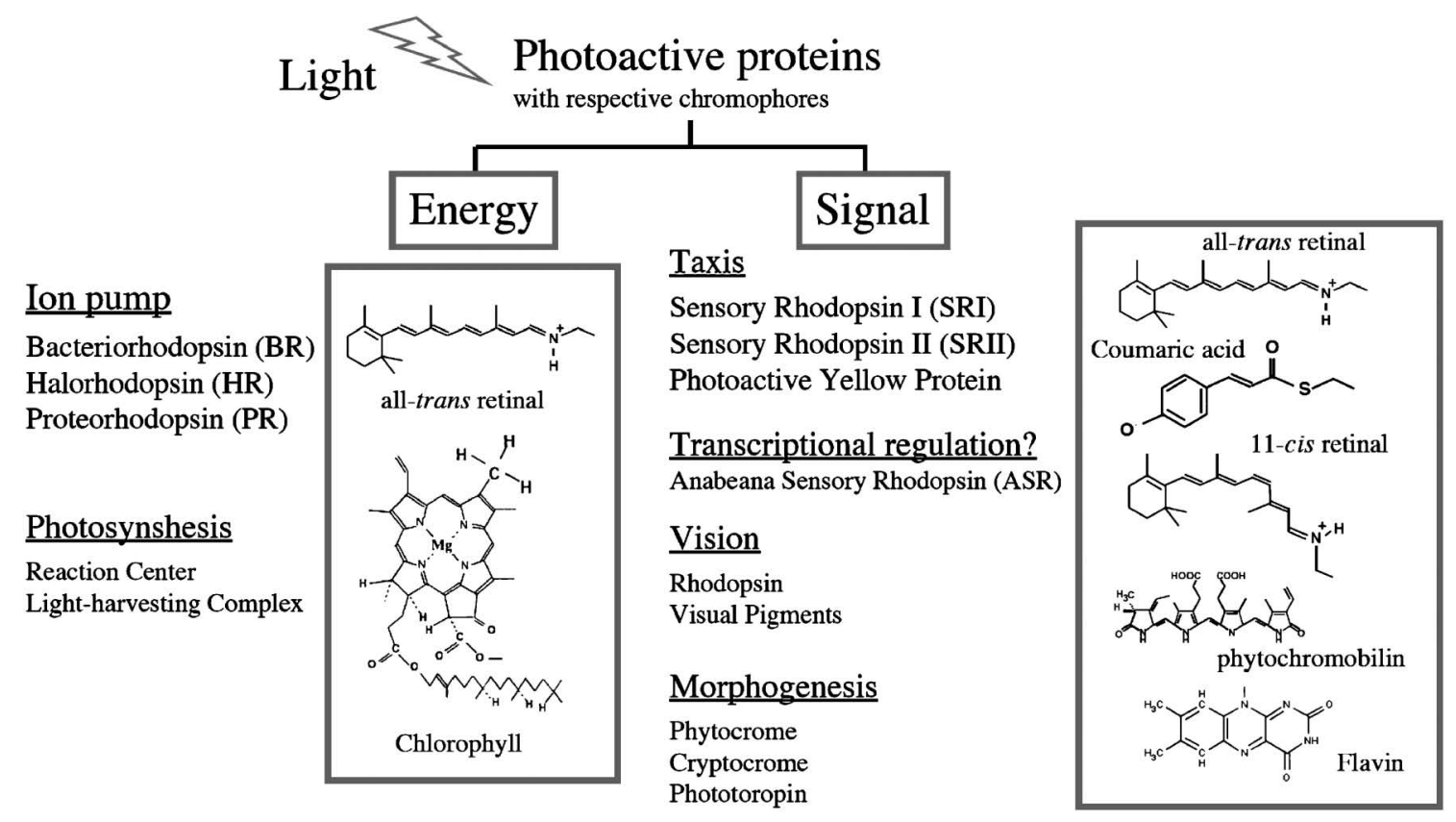

Fig. 1. Photoactive Proteins and Their Chromophores

Although the photoactive proteins have seemingly dissimilar functions, they can be roughly divided into two basic functions, light-energy conversion and lightsignal transduction.

る）を発色団として持つ， 7 回膜貫通型光受容タン

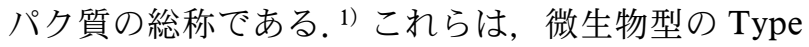
1 と動物型の Type 2 に大別され，他の光受容タン パク質にはない，多彩な機能と色を保持することを 特徵とする [Figs. 1 and 2(A)]。われわれの視覚を 司る視物質ロドプシンや，イオンポンプとして，微 生物のエネルギー産生を司るバクテリオロドプシン （BR）に代表されるこれら分子の研究により，創薬 ターゲットとして重要な膜タンパク質, あるいは光 受容タンパク質全般の理解が大きく進んできた.

私は，見た目の美しさに魅了され [Fig. 2(A)]， 微生物の光センシングに係わるロドプシン分子, セ ンサリーロドプシン II (SRII) (フォボロドプシン とも呼ばれる）の発見者である，北海道大学大学院 薬学研究科・加茂直樹教授の研究室で, 1999 年に 研究をスタートさせた。その頃は，ロドプシンタン パク質が, ヒトを始めとした高等生物と, 高度好塩 性古細菌に存在する稀なタンパク質だと考えられて いたが, ゲノム解析により, 現在では様々な生物種 から 5000 ほどの分子が発見され，ロドプシン類が 生物界に広く分布していること, すなわち様々な生 物にとって，ロドプシンを介した光受容が生命機能 に重要であることが明らかになりつつある。これら 新規タンパク質については別の総説に詳しい. ${ }^{3)}$
3. 微生物型センサーロドプシン

生物は過酷な外部環境変化にさらされるため, 多 種多様なセンサータンパク質を発達させてきた。セ ンサー型ロドプシンもその 1 つである。 ヒトは, 青・緑・赤（いわゆる 3 原色）の光を吸収する 3 種 類のロドプシンタンパク質により, 絵の具の混じり 合わせのように“色”を見分けている $[$ Fig. 2(B) ]. 一方で，ある種の微生物も青色と緑色を受容するロ ドプシンタンパク質により，色を見分けていること [Fig. 2(B)] はあまり知られていない。ここで, SRII とセンサリーロドプシン I (SRI) は, 運動器 官であるべん毛モーターの回転方向を調節し，遊泳 方向を制御する。その結果, SRII は DNA に障害 を与える光からの逃避運動の受容体として, SRI は 誘因応答受容体として, 吸収波長域が重なる BR を 駆動することで, 膜内外のプロトン濃度勾配を産生

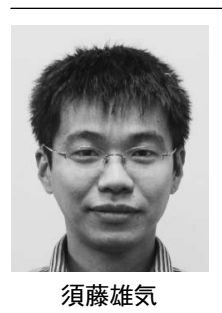

名古屋大学理学研究科准教授. JST さ きがけ研究員 (兼任). 1977 年神奈川 県生まれ。北海道大学薬学部卒業. 同 修士 - 博士課程修了 (その間, 奈良先 端大特別研究学生). 名古屋工業大学术 スドク, テキサス大学ポスドクを経て 名古屋大学助教. 2009 年より現職. 口 ドプシンの発掘・解析・利用を目指し ている. 


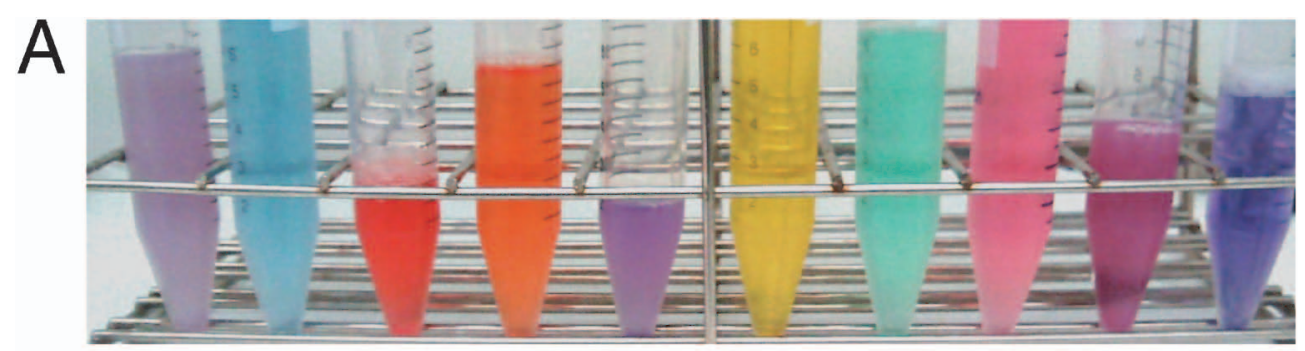

$\mathrm{B}$
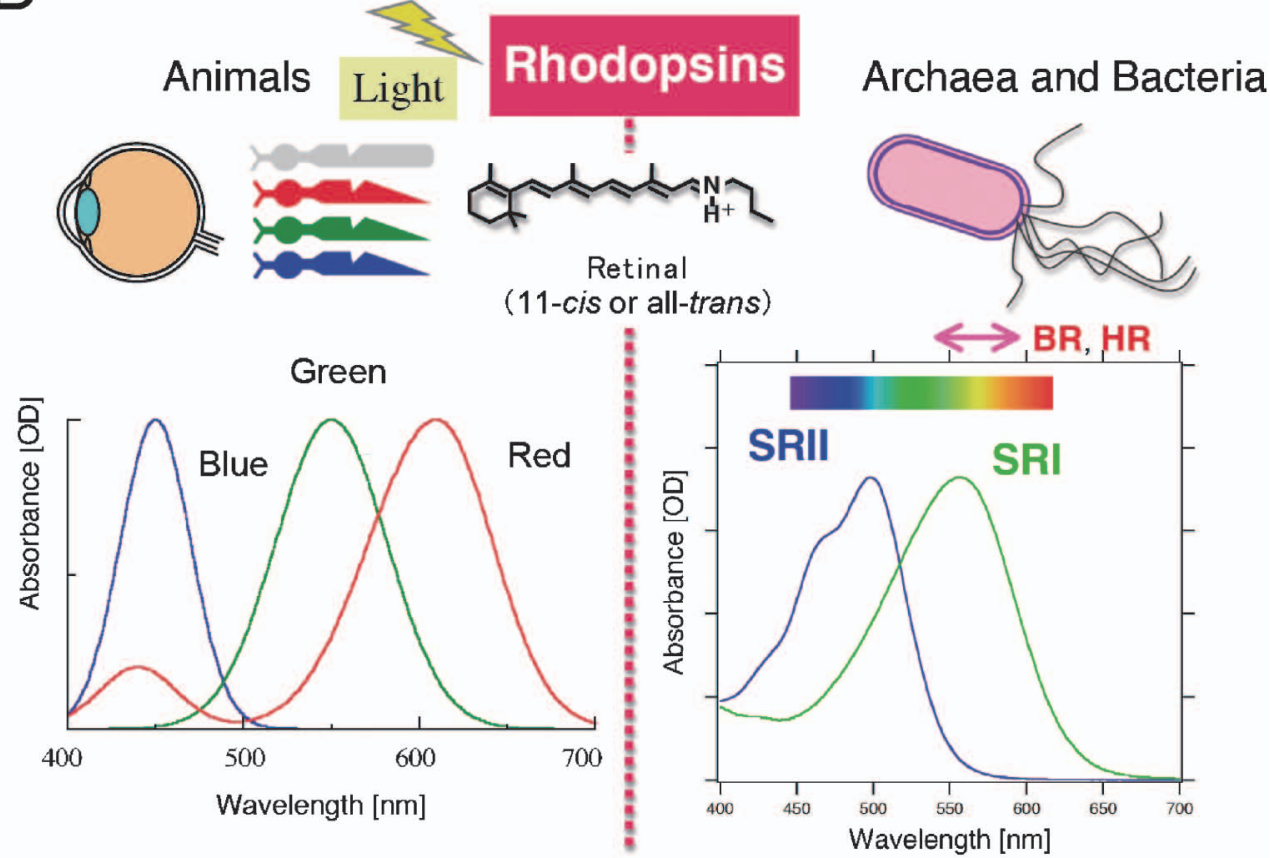

Fig. 2. A, Purified Microbial Rhodopsin Molecules from Various Microbes. B, Photosensory Rhodopsins from Animals and from Both Archaea and Bacteria

し，ATP 合成酵素を介して ATP を合成する. ${ }^{1)}$ 以 下，4. センサリーロドプシンがどのように生まれ てきたのか (分子進化)，5.色制御機構，6. 光化学 反応, 7. 発色団, タンパク質の構造変化及び伝達 タンパク質への情報伝達機構に分けて概説する.

\section{4. センサリーロドプシンの分子進化}

SRI や SRII はどのように生まれてきたのだろう か? われわれは実験的にこの問題の解明に取り組 んでいる.この問いに答えることは, 究極的には, われわれの手で人工的な光受容タンパク質を構築で きることを意味する. これまでの遺伝学的解析から,

SRI や SRII は， BR やハロロドプシン（HR）など の光駆動イオンポンプ型ロドプシンから進化してき

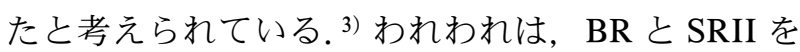
題材に, 両者間の機能変換を実現することで, 進化 過程を考察することとした，SRII は，細胞膜上で 伝達タンパク質・HtrII と複合体を形成している
（Fig. 3 点線内）。 2) われわれは，大腸菌，好塩菌， 酵母, 無細胞系などを駆使して, 難しいとされる膜 タンパク質の安定・大量発現系の構築に取り組んで いる [Fig. 2(A)]. 1) これらのうち, SRII-HtrII 複 合体及び，SRII 単体を用いて，そのイオン輸送能 を測定した。その結果，SRII-HtrII 複合体から HtrII を除去すると, 弱いながらイオン（プロトン） 輸送に伴う電圧変化が観測されることがわかつ

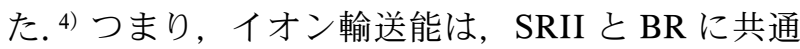
の性質であることがわかった.

次に BR $\rightarrow$ SRII-HtrII の機能変換を試みた。変換 に先立ち, SRII と HtrII の膜タンパク質間相互作 用の検出系を確立し, ${ }^{5)}$ 結合には, SRII の 2 つの極 性アミノ酸（Thr189，Tyr199: Fig. 3, Thr, Tyr）が 重要であることを示した. ${ }^{6-8)}$ 次に, これらのアミ ノ酸を BR に導入したところ，HtrII との結合能を 獲得することがわかった。 ${ }^{9)}$ 一方で，この複合体 


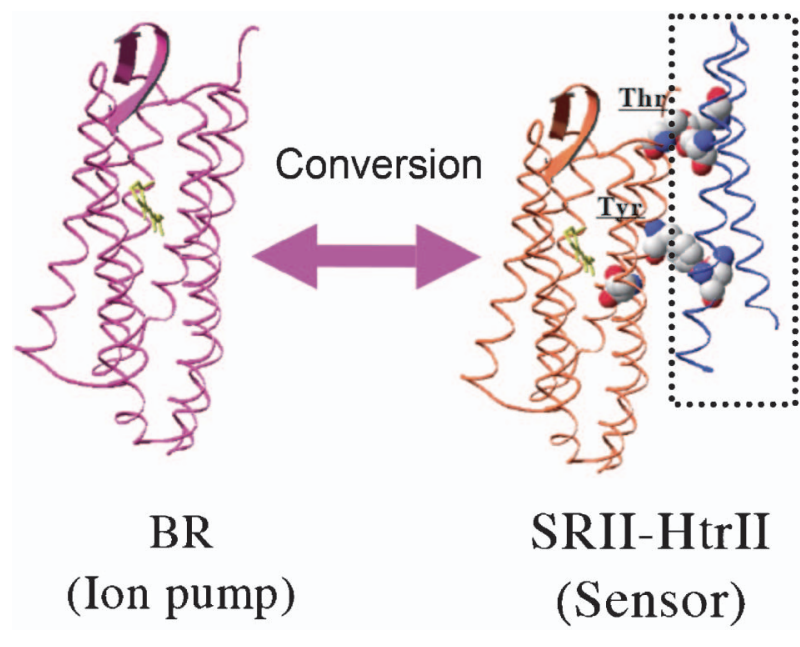

Fig. 3. Functional Conversion between a Light-driven Proton Pump (BR) into a Photosensor (SRII-HtrII)

は, 細菌の光運動性変化を引き起こさなかった。 そ こで, SRII-HtrII に立ち戻り, 様々な変異体を作成 し，機能発現に重要なアミノ酸を探索したところ,

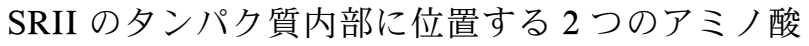
（Tyr174, Thr204）が機能に必須であることがわか つた. ${ }^{10)}$ Tyr174 は BR にも保存されているため, Thr204 に対応するアミノ酸を, 先の 2 重変異体に 導入したところ，この変異 BR-HtrII 複合体は, SRII と同様に忌避応答の光センサーとして機能で

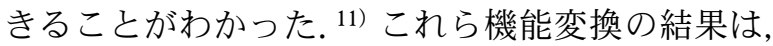
BR と SRII の比較的低い相同性（26\%）にもかか わらず，基本的な性質は両者間で保持されているこ とを示唆している. ${ }^{1)}$ 実際に, SRII の結晶構造は, BR のそれと非常によく似ていることがわかってい る（主鎖 Ca の RMSD は 1 A 程度, Fig. 3). 12)

機能変換の解析から, 光エネルギー変換タンパク 質から，光センサータンパク質への分子進化は，わ ずか 3 つのアミノ酸の変異が主導的な役割を果たし たことが明らかとなった。一方で，作成した光セン サ一型変異 BR-HtrII 複合体の吸収極大波長は，BR とほぼ同一であり, 有益な光からの逃避を促すあま のじゃくな分子を作り出したことになる，また，発 色団の異性体組成や光反応速度など, 実際に SRII を光センサーたらしめる部分は変換されなかっ た。 2006 年に独グループが, 正方形の古細菌 Haloquadratum walsbyi のゲノム配列を報告し

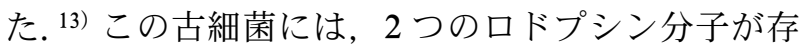
在していた。1つは, BR と類似性の高い遺伝子

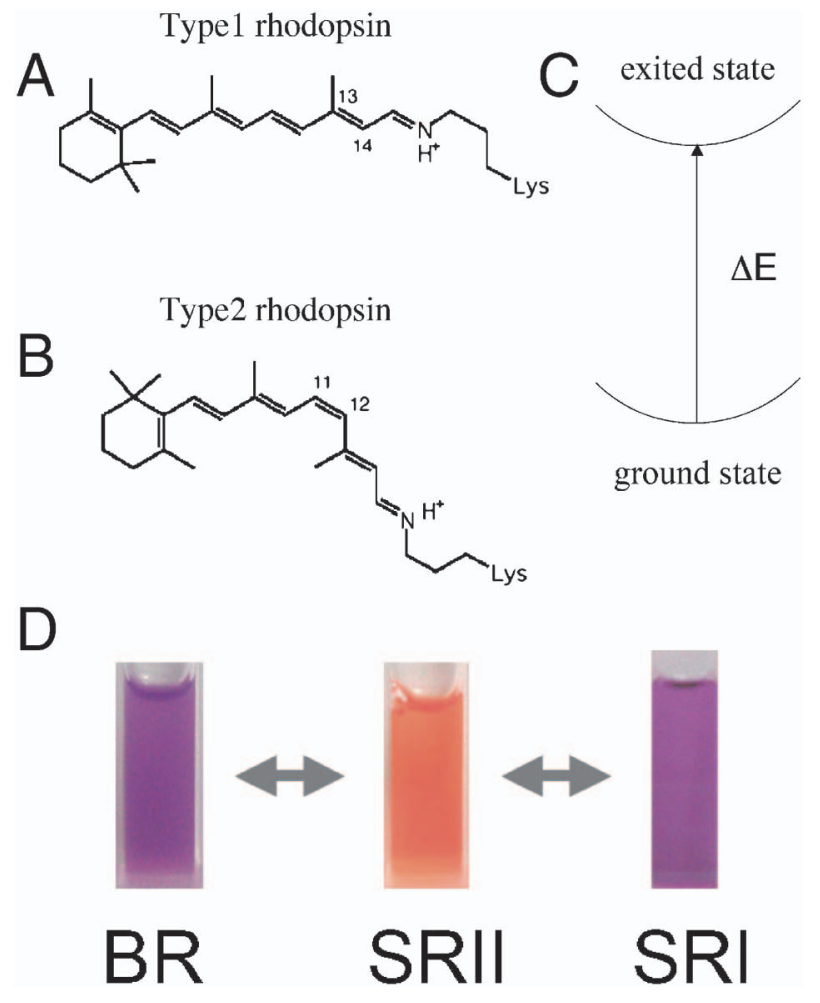

Fig. 4. Chromophore Structure and Color of Rhodopsins

A and B, Chromophore structures in Type 1 and Type 2 rhodopsins; C, Rhodopsins show characteristic colors originating from an energy gap between the ground and excited states, which lead to changes in the absorption maximum. D, Color of BR from the archaeon Haloquadratum walsbyi, SRII for the archaeon Natoronomonus pharaonis and SRI from the eubacterium Salinibacter ruber.

(bopI） で，もう 1 つは，系統樹的に BR と SRII のちょうど中間に位置し, 機能変換に必須の $\mathrm{Thr}$ 残基 ${ }^{10)}$ を持つ遺伝子 (bopII) であった。分子進化 の手がかりを得るために, bopII 遺伝子をクローニ ングし，発現・精製を行った（Middle Rhodopsin, MR と命名). 種々の分光学的・生化学的解析の結 果, この分子の吸収極大波長は SRII 型, 光反応は BR 型であることがわかった. ${ }^{14)}$ また，人工的に作 成した MR-HtrII 複合体は，正常な忌避応答の光セ ンサーとして機能することがわかった．これらの結 果から，進化の初期段階で色が大きく変化したこ と, その後光反応の遅延と伝達タンパク質との相互 作用が起こつたことを考察した. ${ }^{14)}$ また, 思わぬ副 産物として，Type-1 ロドプシンとしては初めてヒ トなどと同様に，11-cis 型レチナールを発色団とし て持つことがわかつた [Fig. 4(A)]。もしかしたら これまで進化的な関係がないと言われてきた Type 1 型と Type 2 型ロドプシンをつなぐミッシングリ ンクではないかと考え，さらなる解析を行ってい 
る.

\section{5. 色制御機構}

光受容タンパク質は, 機能発現のために, 適切な 波長の光を認識する必要がある。そのため, 固有の 吸収波長特性を有する。一般に，光受容タンパク質 は，吸収特性の異なる発色団を取り込むことで，様 々な色を実現する（Fig. 1）。多様な色の光を認識 するために，合目的かつ合理的であると思われる．

一方で，ロドプシンタンパク質類は，レチナールと いう同一の発色団［Figs. 4(A) and（B)］を持ちな がら，350-600 nm の幅広い極大吸収波長を持つこ とを特徵とする $[$ Fig. 2(A) ]。レチナールに限ら ず，発色団の吸収極大波長（色）は，基底状態と励 起状態のエネルギー差により説明される [Fig. 4 (C) ]. 色制御の分子メカニズムは, 研究対象とし ての面白さから, 物理学者, 化学者, 生物学者が理 論・実験の両面から様々な解析を行っているが, 1 つ強調したい点は，タンパク質場の役割である。す なわち，モデル系とされる溶液系では，溶媒やレチ ナールシッフ塩基の対イオンをどう選んでも， 50 $\mathrm{nm}$ 程度の波長シフトに留まり，特に $500 \mathrm{~nm}$ 以上 の吸収は実現できない.

私たちは, タンパク質場, 特にアミノ酸残基の役 割を検討するため, 比較的タンパク質発現が容易な BR と SRII［Fig. 4(D)］を題材に，BR 型のアミノ 酸残基に置換した SRII 変異体を作成し，色制御機 構を解析した。 その結果, 発色団レチナール近傍の 3つのアミノ酸が色制御に重要な役割を果たすこと だけでなく, 15) キメラタンパク質の解析から，一見 レチナールの電子状態に影響を及ぼさないと予想さ れる発色団から $10 \AA$ 以上離れた部位も色制御に重 要であることを明らかにした。 ${ }^{16)}$ 一方で，BR SRII との間には，色以外にも，機能，異性体組 成，光反応などに違いがあり，波長制御機構に絞つ た解析が難しかった。そこで，BR と同様の吸収極 大波長を持ち [Fig. 4(D)], SRII と類似の機能, 異性体組成，光反応を持つSRI を材料にさらなる 検討を行つた。これまで研究に用いられてきた SRI 分子は極めて不安定なタンパク質であったため，ゲ ノム配列を基に，新しい SRI 分子をクローニング し，発現・精製系の構築を試みた。その結果，真正 細菌 Salinibacter ruber 及び，古細菌 Haloarcula vallismortis から，安定な SRI ホモログを得ること
に成功し，それぞれ $S r S R I, H \nu$ SRI と名付けた。 ${ }^{17,18)}$

これら新規 SRI 分子から，新しい色制御メカニ ズムがわかってきた。すなわち SRI のレチナール の $\beta$ イオノン環近傍の保存された His 残基に，ア ニオン（生理的には $\mathrm{Cl}^{-}$） が結合し，20 nm 程度の 長波長化を引き起こすことがわかった（Fig. 5). 18,19) また，網羅的な変異体解析から新たな色制御残基を 同定することに成功した. ${ }^{20)}$ 近年，光による細胞・ 個体操作の進展により，色制御メカニズムの理解と それに基づくカラーバリアントが渴望されている.

私たちは，世界的に最も長波長・短波長のロドプシ ン分子を保持する研究グループとして，SRIIや SRI だけでなく， BR や他のロドプシンタンパク質 においても，色制御機構の研究を行っており，その 要求に応えていきたいと考えている.

\section{6. 光化学反応}

光を受けたロドプシン分子は，数百フェムト秒と いう超高速でトランス体からシス体への発色団異性 化反応を高い量子収率 $(\sim 0.7)$ で実現する. ${ }^{21)}$ そ こでの高エネルギー状態は，様々な中間状態を経 て，数ミリ秒から秒の時間をかけて徐々に熱的に緩 和する，通常のタンパク質では，このような高速反 応を直接捉えることは容易ではないが，光受容タン パク質は，光で反応を開始できる特性から，多方面 の解析が行われてきた. Figure 6 に吸収極大変化か ら提唱された SRI と SRII の光反応サイクルを示し た. ${ }^{2)}$ 吸収変化は，発色団の変化に対応するため, 吸収変化を伴わない構造変化は，この反応サイクル

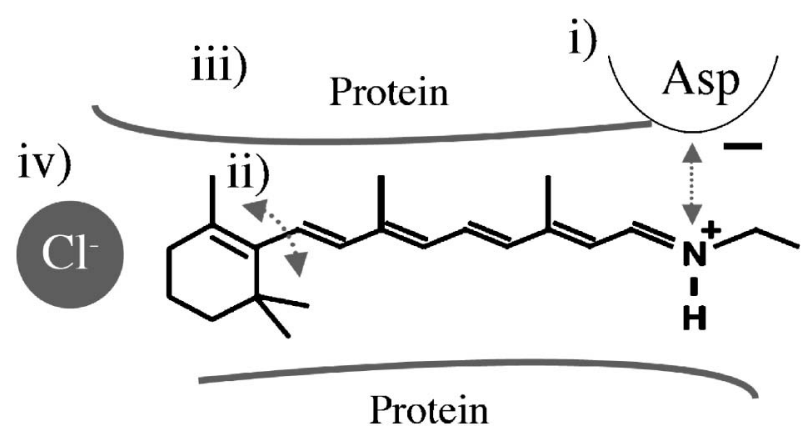

Fig. 5. Color Tuning Mechanisms in Rhodopsin

(i) An alteration in the strength of the electrostatic interaction between the protonated Schiff base and its counter ion or hydrogen bond acceptor (ii) an alteration in the polarity or polarizability of the environment of the chromophore-binding site, caused by the arrangement of polar or aromatic residues; (iii) an isomerization around the 6-S bond (6,7-torsion angle) connecting the polyene chain to the $\beta$-ionone ring; and (iv) $\mathrm{Cl}^{-}$binding around the $\beta$-ionone ring. 
(A)

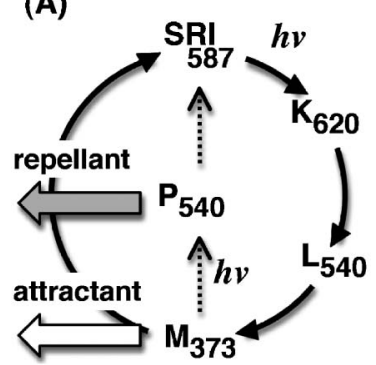

(B)

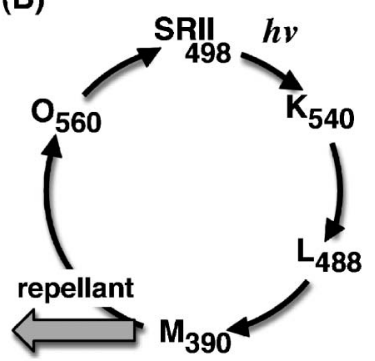

Fig. 6. Photochemical Reaction Cycles of SRI (A) and SRII (B)

SRI absorbs orange light and forms K (K620), L (L540) and the longlived $\mathrm{M}$ intermediates (M373), which forms the P intermediate (P520) upon the second photon absorption in the near-UV region. SRII absorbs blue light and forms K (K540), L (L488), M (M390), and O (O560) intermediates. The $\mathrm{M}$ and $\mathrm{O}$ intermediates are thought to be active states.

には反映されない，実際に，最近われわれは，SRI の M 状態には，3 つの状態（M1，M2，M3）が存在 することを，過渡回折格子法により明らかにし た. 22)また，われわれは，光励起に伴って，SRII 分子内で塩基性及び酸性アミノ酸間でプロトンの授 受, すなわち側鎖の $\mathrm{p} K_{\mathrm{a}}$ 変化が起こることを見い 出し, その変化が, センサー型ロドプシンに特徵的 な遅い光反応（M 及び $\mathrm{O}$ 中間体の長寿命化）を実 現していることを突き止めた. ${ }^{23-26)}$ 一般に，イオン ポンプ型ロドプシンは，1 反応サイクルあたり 1 つ のイオンを輸送するため, 光反応が速ければ速いほ ど優れたポンプとなる. 一方, センサー型ロドプシ ンは, 暗状態で不活性型で, 光刺激により生成する $\mathrm{M}$ 中間体が活性型となる。 そのため, 活性化状態 を長く保つことが, 伝達タンパク質の活性化に重要 であると考えられている. ${ }^{1,2)}$ 次に伝達夕ンパク質の 影響について述べる. 時間分解過渡吸収変化解析か ら，SRI 及び SRII が，HtrI 及び HtrII と結合する と，それぞれ活性型 $\mathrm{M}$ 中間体が長寿命化すること

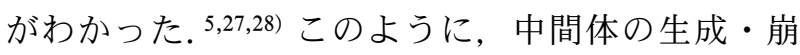
壊を伴う光反応過程は分子内でのプロトン, イオン や水分子などの移動による $\mathrm{p} K_{\mathrm{a}}$ の変化により説明 されるが，これらを実際に駆動するのは発色団や夕 ンパク質の構造変化であり, 当然ながらロドプシン タンパク質の機能発現とも密接に関係する. 次にそ れらの解析結果について述べる。

7. 発色団·タンパク質の構造, 構造変化と伝達 タンパク質への情報伝達機構

ロドプシンタンパク質は，各種測定のプローブと

なる発色団レチナールを内包している $[$ Figs. 4(A) and (B) ]. また, 光化学反応は, 初期の異性化反応 を除いて熱的な過程であるため，低温で中間体を卜 ラップすることができる。このような特性から，分 子・原子レベルでの詳細な解析が可能となる。私た ちは青色光受容体・SRII を用いて, 分子構造及び 構造変化の解析に有用な赤外, ラマン, NMR など 各種分光法を用いた解析を行っている. 2003 年に, $\mathrm{K}$ 中間体形成時に, 大きな水素結合を示す $\mathrm{OH}$ 基 を発見した. ${ }^{29)}$ 変異体を用いた解析からこの $\mathrm{OH}$ 基 は, SRII の Thr204 に由来するものと同定した. ${ }^{30)}$ 2005 年には, レチナールの C-H を C-D に置き換え た合成レチナールを用い, $\mathrm{K}$ 中間体形成時に 14 位 の $\mathrm{C}-\mathrm{H}$ 基が大きな立体障害を起こすことを明らか

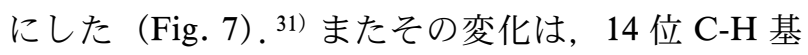
の水素面外偏角振動においても確かめられた. ${ }^{32)} さ$ らには, 変異体と同位体を用いて, そのカウンター パートが Thr204 であることも確かめ, これら振動 強度の変化が実際の機能 (走光性) の効率と正の相 関があることを明らかにした。 ${ }^{33)} \mathrm{Thr} 204$ が機能に 必須であること，実際の情報伝達は $\mathrm{M}$ 中間体時に 起こることと併せて，Thr204 が直接 HtrII への情 報伝達を担うのではなく, 光異性化直後の高エネル ギー状態を Thr204 とレチナールの立体障害として 蓄え，そのエネルギーにより HtrII を活性化すると

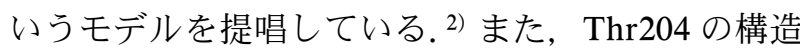
変化に先立って, ピコ秒領域 ( $\mathrm{J}$ 中間体) において,

Thr204 の水素結合パートナーであり, 機能に必須 のアミノ酸である Tyr174 に構造変化が起こること を紫外共鳴ラマン分光法により明らかにしてい る. ${ }^{34)}$

次に, 活性型 $\mathrm{M}$ 中間体時にはどのような構造変 化が起こるのであろうか. $\mathrm{M}$ 中間体とのみ反応す る種々の水溶性試薬との反応性解析から, SRII の 6 番目 (F) ヘリックスの細胞質側が, 大きく構造 変化することを報告した. ${ }^{35-37)}$ また, $\mathrm{M}$ 中間体時に HtrII との結合が弱まること, その結合能の低下が SRII と HtrII の細胞質ドメイン (HAMP ドメイン) の解離により引き起こされるモデルを提唱してい る. ${ }^{38,39)}$ 独グループの報告によると，その際に HtrII の 2 番目のヘリックスが回転することがわか つている. ${ }^{40)}$

このように, 受容体（SRII）から伝達タンパク 

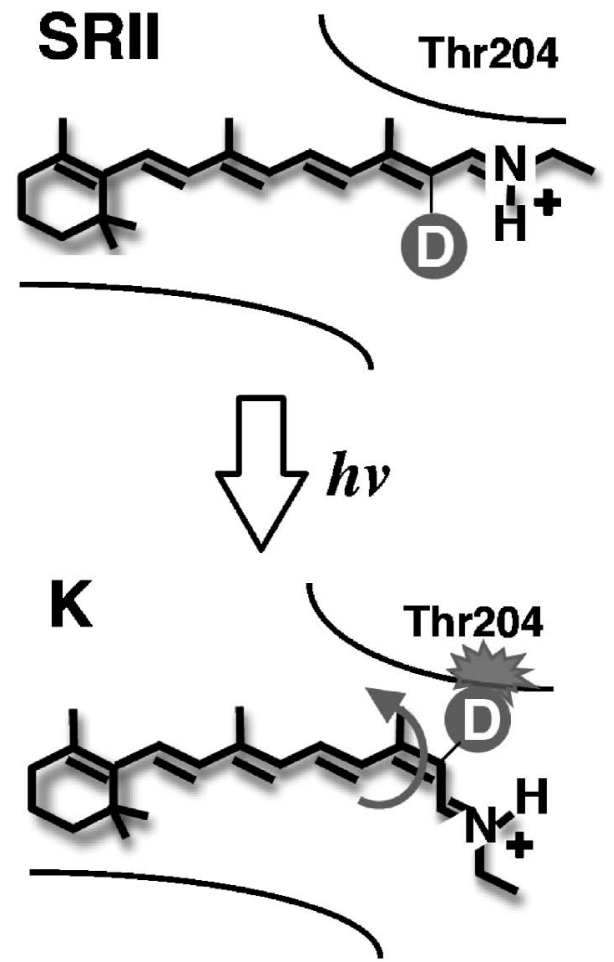

Fig. 7. Structural Change of the Retinal Chromophore upon Formation of the K Intermediate of SRII

The enhanced $\mathrm{C}_{14}$-D stretch in the $\mathrm{K}$ intermediate was assigned as the band originating from the local steric constraint between $\mathrm{C}_{14} \mathrm{D}$ and Thr $204_{\text {SRII. }}$ We reported that the band intensity correlated well with the phototaxis signaling efficiency, indicating its functional importance.

質（HtrII）への情報伝達メカニズムの理解は進ん できた。一方で，HtrII より下流のシグナル伝達因 子（アダプタータンパク質 $\mathrm{CheW}$ ，キナーゼ CheA，レスポンスレギュレーター CheY）への情 報伝達メカニズムは理解されたとは言い難い。最も 大きな理由は, Htr 分子の全長での発現が難しく, 膜貫通部位以降を切除した変異体（Fig. 3）が用い られてきたことによる。私が卒業研究以来取り組ん できたこの課題は，S. ruber 由来の Htr を用いるこ とで解決した。 すなわち，量は少ないものの，SRHtr 全長タンパク質を，遺伝子工学的操作が容易な 大腸菌で発現させることに成功した. ${ }^{28)}$ 今後は, 取 り組み始めた出力器官・ベん毛モーターの解析 ${ }^{41)} も$ 含めて，これまで類推に留まってきたシグナル伝達 機構を分子・原子レベルで解明したいと考えている.

また，緑色光受容体・SRI から伝達タンパク質 （HtrI）への情報伝達メカニズムの理解にも取り組 んでいる．先述の安定な SRIを用いて，これまで 難しかった解析が可能となり，SRII とは逆方向の
タンパク質骨格の構造変化や，水分子の構造変化を 明らかにするとともに, ${ }^{42)}$ Asp102, His131, Cys132 など，SRIにおいて光依存的な構造変化を起こすア ミノ酸残基がレチナールの $\beta$ イオノン環近傍に局 在していることを報告した. ${ }^{43)}$ SRII の機能がレチ ナールのシッフ塩基近傍により制御されることか ら，異なる構造変化は，異なる部位での構造変化に 由来するものと考えられる (Fig. 5).

\section{8. ロドプシンを利用した光操作ツールの開発}

ここまで，基礎的で難解な内容を読んで頂いた読 者の方々に深く感謝する。薬学部出身の私がこのよ うな基礎的研究を行っているのは，ロドプシンタン パク質類が，広く生命科学者が利用できるツールに なり得るとの確信に基づいている．光受容タンパク 質の 1 つであり，ノーベル賞でも有名な GFP（緑 色蛍光タンパク質）の利用により，生命現象を可視 化することが可能となり, 生命科学研究に革命が起 こったことは既にご存じの通りである．FRET (Förster resonance energy transfer) と組み合わせる ことで，様々な化学物質の可視化が可能となるな ぞ，応用範囲は留まるところを知らない。しかしな がら，基本的に光るのみの蛍光（あるいは発光）分 子は，光により細胞や個体の動態を直接制御するこ とを苦手としてきた，それを可能とするのがロドプ シンなどの光吸収タンパク質である。実際に真核生 物コナミドリムシ由来のチャネルロドプシンは，光 刺激によりカチオンを透過することが可能な分子で ある. ${ }^{44)}$ 神経活動を正に制御することが可能で，神 経ネットワークの解析や細胞・個体の光活性化に利 用されている．また，光で細胞内から細胞内へプロ トンを輸送する BR とともに，細胞外から細胞内に $\mathrm{Cl}^{-}$をポンプする $\mathrm{HR}$ を用いることで，神経活動を 負に制御できることも報告されている（Fig. 8). ${ }^{45)}$

私たちは，センサー型ロドプシンの利用について の研究を行っている，例えば，藻類アナべナにある アナベナセンサリーロドプシン（ASR）が，直接 遺伝子発現を調節していることを確かめ, 光により 任意のタンパク質量を増加させることが可能である ことを明らかにした. ${ }^{46)}$ また，先述の SRI は，緑色 光受容により, キナーゼ CheA の不活性化を引き起 こすだけでなく，青色光による 2 光子反応により， 活性化も引き起こすことができる，CheA は，マス ターレギュレーターとして，様々な刺激に対する応 


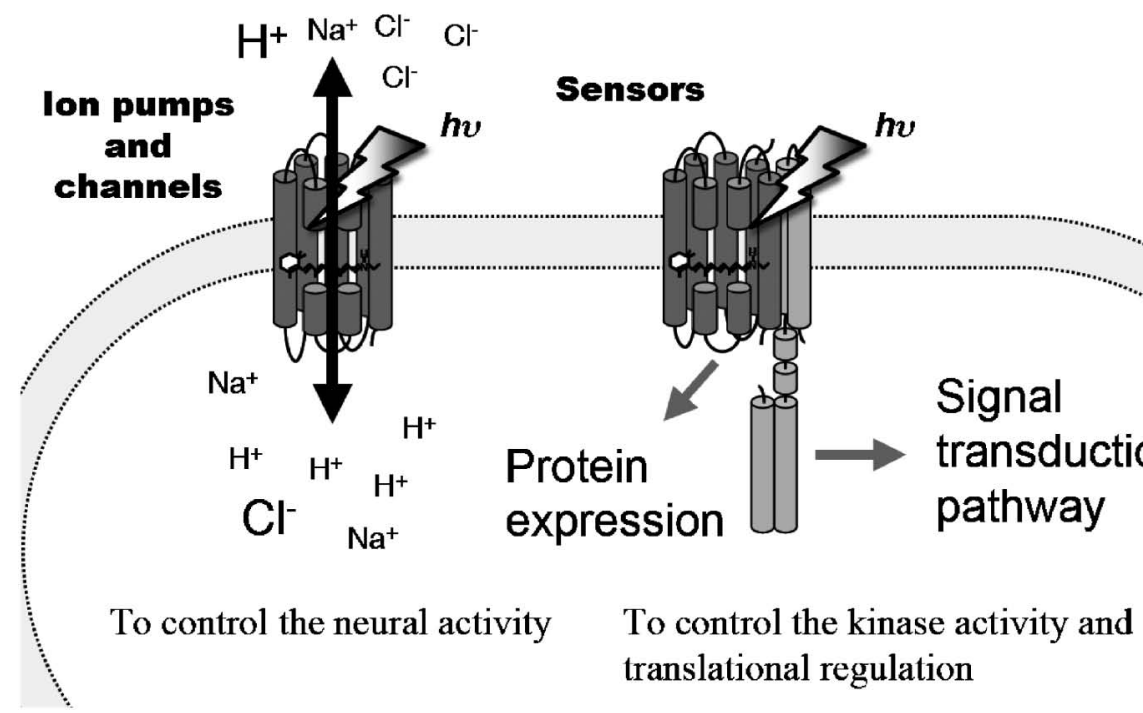

Fig. 8. Microbial Rhodopsin Molecules are Useful for Controlling the Several Activities of the Cells

答を制御する. 2 成分制御系とも呼ばれるこれらシ グナル伝達系は, 原核生物, 菌類, 植物などに広く 存在する．これらを光により制御することで，細胞 や個体の性質を制御できる可能性がある（Fig. 8).

4. の分子進化の解析により, タンパク質機能の変 換が，5.の色制御機構解析により，カラーバリア ントの作成が，6.の光化学反応の解析により, 活 性化状態の寿命制御が，7.の情報伝達メカニズム の理解により, シグナル伝達自体の改変が, 可能と なる，将来的には，これら基礎研究を礎に，新しい 光ツールを開発していきたい.

最後に,一言お願いしたい。薬学部生は, 薬理 学，臨床薬学など薬に直結したことを学ぶだけでな く, 有機化学, 物理化学, 生化学など広く基礎的な 学問を一通り学ぶ。このような背景は, 薬学部出身 の諸先輩方が広く基礎系の研究者として大成する道 を開いてきた。薬学部が 6 年制となり，求められる 薬学部像も変遷を遂げているが, 広い知識と視野を 持った薬学部生は，基礎的研究の分野で強く望まれ ていることは間違いない。是非とも，資源の乏しい 国日本の屋台骨を支える基礎研究に, 多くの薬学部 生が参画してくれることを願ってやまない.

謝辞こここで取り上げた研究成果は, 参考文献 中の共同研究者の貢献なしには得ることができませ んでした. 特に, 北海道大学・加茂直樹教授（現 ・ 松山大学), 名古屋工業大学・神取秀樹教授, テキ
サス大学・John L. Spudich 教授に深く感謝致しま す.

\section{REFERENCES}

1) Sudo Y., "CRC Handbook of Organic Photochemistry and Photobiology," 3rd ed., CRC Press, Boca Raton, 2012, pp. 1173-1193.

2) Suzuki D., Irieda H., Homma M., Kawagishi I., Sudo Y., Sensors, 10, 4010-4039 (2010).

3) Sharma A. K., Spudich J. L. Doolittle W. F., Trends Microbiol., 14, 463-469 (2006).

4) Sudo Y., Iwamoto M., Shimono K., Sumi M., Kamo N., Biophys. J., 80, 916-922 (2001).

5) Sudo Y., Iwamoto M., Shimono K., Kamo N., Photochem. Photobiol., 74, 489-494 (2001).

6) Sudo Y., Iwamoto M., Shimono K., Kamo N., Biophys. J., 83, 427-432 (2002).

7) Sudo Y., Iwamoto M., Shimono K., Kamo N., J. Photochem. Photobiol. B, 67, 171-176 (2002).

8) Sudo Y., Yamabi M., Iwamoto M., Shimono K., Kamo N., Photochem. Photobiol., 78, 511 -516 (2003).

9) Sudo Y., Yamabi M., Kato S., Hasegawa C., Iwamoto M., Shimono K., Kamo N., J. Mol. Biol., 357, 1274-1282 (2006).

10) Sudo Y., Furutani Y., Kandori H., Spudich J. L., J. Biol. Chem., 281, 34239-34245 (2006).

11) Sudo Y., Spudich J. L., Proc. Natl. Acad. Sci. USA, 103, 16129-16134 (2006). 
12) Luecke H., Schobert B., Lanyi J. K., Spudich E. N., Spudich J. L., Science, 293, 1499-1503 (2001).

13) Bolhuis H., Palm P., Wende A., Falb M., Rampp M., Rodriguez-Valera F., Pfeiffer F., Oesterhelt D., BMC Genomics, 7, 169 (2006).

14) Sudo Y., Ihara K., Kobayashi S., Suzuki D., Irieda H., Kikukawa T., Kandori H., Homma M., J. Biol. Chem., 286, 5967-5976 (2011).

15) Shimono K., Ikeura Y., Sudo Y., Iwamoto M., Kamo N., Biochim. Biophys. Acta, 1515 , 92-100 (2001).

16) Shimono K., Hayashi T., Ikeura Y., Sudo Y., Iwamoto M., Kamo, N., J. Biol. Chem., 278, 23882-23889 (2003).

17) Kitajima-Ihara T., Furutani Y., Suzuki D., Ihara K., Kandori H., Homma M. Sudo Y., J. Biol. Chem., 283, 23533-23541 (2008).

18) Yagasaki J., Suzuki D., Ihara K., Inoue K., Kikukawa T., Sakai M., Fujii M., Homma M., Kandori H., Sudo Y., Biochemistry, 49, 1183-1190 (2010).

19) Suzuki D., Furutani Y., Inoue K., Kikukawa T., Sakai M., Fujii M., Kandori H., Homma M., Sudo Y., J. Mol. Biol., 392, 48-62 (2009).

20) Sudo Y., Yuasa Y., Shibata J., Suzuki D., Homma M., J. Biol. Chem., 286, 11328-11336 (2011).

21) Polli D., Altoè P., Weingart O., Spillane K. M., Manzoni C., Brida D., Tomasello G., Orlandi G., Kukura P., Mathies R. A., Garavelli M., Cerullo G., Nature, 467, 440443 (2010).

22) Inoue K., Sudo Y., Homma M., Kandori H., J. Phys. Chem. B, 115, 4500-4508 (2011).

23) Iwamoto M., Hasegawa C., Sudo Y., Shimono K., Araiso T., Kamo N., Biochemistry, 43, 3195-3203 (2004).

24) Ikeura Y., Shimono K., Iwamoto M., Sudo Y., Kamo N., Biophys. J., 86, 3112-3120 (2004)

25) Iwamoto M., Sudo Y., Shimono K., Araiso T., Kamo N., Biophys. J., 88, 1215-1223 (2005).

26) Sudo Y., Furutani Y., Iwamoto M., Kamo N., Kandori H., Biochemistry, 47, 2866-2874 (2008).

27) Sudo Y., Iwamoto M., Shimono K., Kamo N., Biochemistry, 43, 13748-13754 (2004) .
28) Sudo Y., Okada A., Suzuki D., Inoue K., Irieda H., Sakai M., Fujii M., Furutani Y., Kandori H., Homma M., Biochemistry, 48, 10136 -10145 (2009).

29) Furutani Y., Sudo Y., Kamo N., Kandori H., Biochemistry, 42, 4837-4842 (2003).

30) Sudo Y., Furutani Y., Shimono K., Kamo N., Kandori H., Biochemistry, 42, 14166-14172 (2003)

31) Sudo Y., Furutani Y., Wada A., Ito M., Kamo N., Kandori H., J. Am. Chem. Soc., 127, 16036-16037 (2005).

32) Sudo Y., Furutani Y., Spudich J. L., Kandori H., J. Biol. Chem., 282, 15550-15558 (2007).

33) Ito M., Sudo Y., Furutani Y., Okitsu T., Wada A., Homma M., Spudich J. L. Kandori H., Biochemistry, 47, 6208-6215 (2008).

34) Mizuno M., Sudo Y., Homma M., Mizutani Y., Biochemistry, 50, 3170-3180 (2011).

35) Sudo Y., Iwamoto M., Shimono K., Kamo N., Biochim. Biophys. Acta, 1558, 63-69 (2002).

36) Yoshida H., Sudo Y., Iwamoto M., Shimono K., Kamo N., Photochem. Phobiol. Sci., 3, 537-542 (2004).

37) Sudo Y., Nishihori T., Iwamoto M., Shimono M., Kojima C. Kamo N., Biophys. J., 95, 753 -760 (2008).

38) Sudo Y., Okuda H., Yamabi M., Fukuzaki Y., Mishima M., Kamo N., Kojima C., Biochemistry, 44, 6144-6152 (2005).

39) Hayashi K., Sudo Y., Jee J., Mishima M., Hara H., Kamo N., Kojima C., Biochemistry, 46, 14380-14390 (2007).

40) Wegener A. A., Klare J. P., Engelhard M., Steinhoff H. J., EMBO J., 20, 5312-5319 (2001)

41) Sudo Y., Kitade Y., Furutani Y., Kojima M., Kojima S., Homma M., Kandori H., Biochemistry, 48, 11699-11705 (2009).

42) Suzuki D., Sudo Y., Furutani Y., Takahashi H., Homma M., Kandori H., Biochemistry, 47, 12750-12759 (2008).

43) Irieda H., Reissig L., Kawanabe A., Homma M., Kandori H., Sudo Y., Biochemistry, 50, 4912-4922 (2011).

44) Nagel G., Ollig D., Fuhrmann M., Kateriya S., Musti A. M., Bamberg E., Hegemann P., Science, 296, 2395-2398 (2002).

45) Zhang F., Aravanis A. M., Adamantidis A., 
de Lecea L., Deisseroth K., Nat. Rev. Neurosci., 8, 577-581 (2007).
46) Sudo Y., Irieda H., Homma M., Japanese Patent, 2010-181053 (2010). 